\title{
GENOSIDA TERHADAP ORANG-ORANG NUSANTARA \\ DALAM ESAI JALAN RAYA POS, JALAN DAENDELS \\ KARYA PRAMOEDYA ANANTA TOER
}

\author{
Mujihadi \\ SMP Negeri 2 Jatirogo Kabupaten Tuban, mujihadijihad@yahoo.com
}

\begin{abstract}
ABSTRAK
Pramoedya Ananta Toer (Pram) banyak menghasilkan karya tulis. Karya tulis itu ada yang berupa novel, drama, esai, dan karya tulis lainnya. Di antara karya esai Pram yang terkenal adalah Jalan Raya Pos, Jalan Daendels (JRPJD). Dalam esai tersebut Pram bercerita tentang terjadinya genosida/pembunuhan masal, baik secara langsung maupun tidak langsung yang telah terjadi di Indonesia. Dalam penelitian ini peneliti akan mengaji esai tersebut menggunakan kritik sastra Kajian Budaya dengan pendekatan historis. Kritik sastra Kajian Budaya dengan pendekatan historis ini merupakan model analisis kualitatif deskriptif. Fokus permasalahan yang dibahas dalam penelitian ini adalah: pertama, bagaimana bentuk representasi genosida terhadap orang-orang Indonesia dalam esai JRPJD karya Pram?; kedua bagaimana klarifikasi sejarah terhadap representasi Pram tentang peristiwa genosida terhadap orang-orang Indonesia dalam esai JRPJD? Dari hasil analisis terhadap esai JRPJD tersebut diperoleh hasil berupa informasi bahwa genosida terhadap orang-orang Indonesia pernah dilakukan oleh orang Belanda, orang Jepang, dan oleh orang Indonesia sendiri. Sedangkan jika diklarifikasi dengan sejarah nasional Indonesia, secara umum apa yang direpresentasikan oleh Pram tentang kisah genosida terhadap orang-orang Indonesia dalam esai JRPJD adalah merupakan peristiwa yang benar-benar pernah terjadi di Indonesia.
\end{abstract}

Kata Kunci: genosida, orang-orang Indonesia, esai JRPJD, Pramoedya Ananta Toer 
Mujihadi, Genosida Terhadap Orang-orang... (hlm. 266-287)

\section{PENDAHULUAN}

Sebagai sastrawan besar Pramoedya Ananta Toer (Pram) telah banyak menghasilkan karya tulis. Dari tangannya yang dingin Pram telah berhasil melahirkan lebih dari lima puluh karya baik fiksi maupun nonfiksi. Dan hebatnya, karya-karya Pram tersebut telah diterjemahkan ke dalam 42 bahasa asing (Toer, 2012:1). Hasil karya tulis Pram itu pun tertuang dalam berbagai bentuk. Ada yang tertuang dalam bentuk novel, naskah drama, maupun esai. Dalam bentuk novel, Pram tercatat - salah satu di antaranya - telah menghasilkan novel tetralogi Buru yang masyhur; dalam bentuk naskah drama, Pram tercatat menghasilkan Mangir; dan dalam bentuk esai, Pram tercatat telah menghasilkan esai: Jalan Raya Pos, Jalan Daendels.

Esai adalah karangan berbentuk prosa yang membahas suatu masalah secara sepintas lalu dari sudut pandang pribadi penulisnya (Tim Penyusun Kamus, Pusat Pembinaan dan Pengembangan Bahasa, 1995:270). Karena ditulis secara sepintas lalu berdasar pada sudut pandang pribadi penulis, maka di dalam menulis esai sangat mungkin pengarang memasukkan unsur subjektivitas diri pengarang sebagai proses kreatif dalam berkarya. Dengan pemahaman seperti ini, maka esai dapat dipandang setara dengan karya sastra. Seperti yang sudah kita ketahui bahwa karya sastra dihasilkan dari proses perenungan dan imajinasi dari dalam diri pengarang. Ketika berkarya seorang sastrawan akan menuangkan imajinasinya. Namun yang perlu diingat adalah kenyataan bahwa ketika menuangkan imajinasinya, seorang pengarang pasti selalu melihat kenyataankenyataan sosial di dalam masyarakat. Dengan melihat kenyataan-kenyataan sosial dalam masyarakat, maka karya sastra yang dihasilkan pengarang tidak akan tercerabut dari masyarakat dan masyarakat akan mampu memahami karya sastra yang dihasilkan oleh pengarang itu. Pernyataan ini sejalan dengan pendapat Ratna 
yang menyatakan bahwa hakikat karya sastra adalah imajinasi tetapi imajinasi yang memiliki konteks sosial dan sejarah (2013:66).

Esai Pram yang berjudul Jalan Raya Pos, Jalan Daendels (JRPJD) adalah esai yang bercerita tentang peristiwa sejarah genosida manusia-manusia pribumi Nusantara di balik pembangunan jalan raya pos atau yang sekarang lebih dikenal dengan nama Jalan Daendels. Di samping kisah sejarah tentang terjadinya genosida dalam pembangunan jalan tersebut, Pram juga berkisah tentang adanya peristiwa genosida lainnya yang pernah terjadi di Indonesia. Peristiwa genosida yang lain itu di antaranya adalah: genosida ketika Belanda melaksanakan kegiatan Tanam Paksa/Cultuur Stelsel, genosida yang dilakukan balatentara fasis zaman pendudukan Jepang, genosida yang dilakukan oleh Kapten Westerling, dan terakhir adalah genosida yang dilakukan oleh penguasa Pribumi terhadap bangsanya sendiri (Toer, 2012:5 - 6).

Sebagai esai yang sarat berkisah tentang peristiwa kelam yang dialami bangsa Indonesia dan tentu saja peristiwa tersebut sangat bisa jadi pernah benarbenar terjadi, maka esai JRPJD ini tentu cocok jika dikaji menggunakan kritik sastra Kajian Budaya dengan menggunakan pendekatan historis. Hal ini senada dengan apa yang dikatakan Ratna (2010:363), yang menyatakan bahwa suatu penelitian dapat menggunakan pendekatan historis apabila penelitian yang dimaksudkan beranggapan bahwa unsur-unsur kesejarahan, baik instrinsik maupun ekstrinsik memegang peranan penting yang pada gilirannya akan menjiwai keseluruhan analisis.

Kritik sastra Kajian Budaya memang cocok digunakan untuk menganalisis berbagai teks. Baik teks itu berupa teks sastra maupun teks nonsastra/wacana lainnya. Hal ini disebabkan karena dalam pandangan kritik sastra Kajian Budaya sudah tidak ada lagi sekat antara karya sastra dan wacana lain, antara fiksi dan nyata, antara sastra serius dan populer, dan seterusnya. Kritik sastra Kajian Budaya menempatkan: karya sastra yang dianggap populer dan serius; karya 
sastra yang dianggap tinggi dan rendah; sebagai suatu objek kajian, semuanya diperlakukan sama berharganya. Hal ini sesuai pendapat Faruk yang menyatakan bahwa Kajian budaya berangkat dari penolakan terhadap pemisahan antara sastra tinggi dan sastra rendah, sastra serius dan sastra populer. Karena pemisahan hierarkis itu dianggap konvensi belaka, kritik sastra dengan perspektif kajiankajian budaya akhirnya menempatkan karya-karya sastra yang dianggap rendah dan populer sebagai objek kajian yang sama berharganya dengan karya-karya sastra yang dianggap tinggi dan serius. Lebih jauh, kritik sastra tersebut bahkan tidak lagi membedakan antara karya sastra dengan wacana-wacana lain, antara fiksi dan nyata, dan seterusnya. Penghapusan pemisahan demikian, pada gilirannya, membawa kritik sastra tersebut ke arah perluasan objek kajian, dari sastra ke berbagai bentuk wacana yang lain (2012:73). Dengan demikian maka dapat dikatakan bahwa objek Kajian Budaya itu sangat luas, yaitu menyangkut berbagai wacana. Hal ini diperkuat dengan penyataan Ratna yang menyatakan bahwa yang menjadi objek Kajian Budaya adalah segala sesuatu yang diperbuat manusia. Teori Kajian Budaya adalah berbagai teori kritis, yaitu teori-teori yang dikelompokkan sebagai postrukturalisme (2010:27). Sejalan dengan Ratna, Faruk juga menambahkan dengan menyatakan bahwa kajian-kajian budaya merupakan kritik sastra dengan rentangan objek dan pendekatan yang amat cair dan dinamis, yang dapat menyerap pendekatan apa pun yang dapat ia gunakan dalam membahas suatu persoalan (2012:74).

Selanjutnya berkaitan dengan analisis historis, Ratna menyatakan bahwa ada tiga kemungkinan terjadinya analisis historis dalam suatu penelitian. Ketiga kemungkinan analisis historis itu adalah sebagai berikut. Pertama, pada dasarnya semua penelitian memiliki unsur sejarah, tetapi seberapa peranannya sehingga pantas untuk dikemukakan sebagai memiliki ciri-ciri pendekatan sejarah diperlukan ketajaman untuk memahami hakikat objek. Cara yang paling mudah 
untuk menganalisisnya adalah dengan cara mengaitkannya dengan sejarah umum, baik dalam ruang lingkup dunia, maupun nasional dan lokal, periode, angkatan, dan zaman. Cara seperti ini disebut analisis historis secara implisit. Kedua, yaitu dengan cara menampilkannya secara eksplisit. Seperti di atas, pada dasarnya semua penelitian memiliki unsur sejarah. Dalam analisis secara eksplisit ini pada umumnya tercantum pada bab gambaran umum, di dalamnya akan disinggung berbagai hal yang berkaitan dengan latar belakang penelitian, termasuk aspek kesejarahannya. Dalam cara kedua ini Ratna memberi contoh, pada saat meneliti mengenai perkembangan pariwisata di Kuta, Sanur, dan berbagai kawasan wisata di Indonesia, misalnya, sering menyinggung kapan wilayah tersebut mulai dikunjungi oleh para wisatawan, hotel dan penginapan pertama yang didirikan, dan mengapa kawasan tersebut menarik minat mereka. Ketiga, sebagai multidisiplin Kajian Budaya dapat menggunakan analisis sejarah, menggabungkannya secara eklektik dengan disiplin lain, dengan catatan bahwa secara hierarkis setiap disiplin yang terlibat dapat ditentukan kedudukannya. Penelitian historis demikian juga model yang lain tentu dengan pertimbangan bahwa melaluinya penelitian akan memiliki nilai tambah terhadap hasil-hasil yang diharapkan. Cara ketiga ini memberi kemungkinan terhadap relevansi bidang keahlian peneliti yang secara kebetulan merupakan seorang sejarawan, sosiolog, psikolog, dan sebagainya. Selanjutnya juga dikatakan oleh Ratna bahwa sesungguhnya secara definitif analisis historis akan menampilkan nuansa masa lampau, suatu citra yang dapat mengantarkan pembaca ke dalam periode tertentu, sehingga hasil analisis mudah dipahami. Oleh karena itulah - masih menurut Ratna - yang lebih penting adalah analisis dengan menggunakan model pertama. Dasar pertimbangannya adalah bahwa unsur-unsur sejarah dalam analisis historis bersifat implisit, fungsinya membantu menjelaskan analisis Kajian Budaya (2010:363 - 367). 
Penelitian Kajian Budaya dengan menggunakan pendekatan historis terhadap esai JRPJD karya Pram ini akan memfokus pada dua pembahasan, yaitu: pertama, bagaimana bentuk representasi peristiwa genosida terhadap orang-orang Indonesia dalam esai JRPJD karya Pram; kedua, bagaimana klarifikasi sejarah terhadap peristiwa genosida yang digambarkan Pram dalam esai JRPJD dengan kenyataan sejarah yang pernah terjadi di Indonesia? Adapun tujuan dari analisis ini adalah: mendeskripsikan tentang bentuk praktik genosida terhadap orangorang Indonesia dalam esai JRPJD karya Pram dan mendeskripsikan klarifikasi sejarah terhadap representasi Pram tentang peristiwa genosida dalam esai JRPJD dengan kenyataan sejarah yang pernah terjadi di Indonesia. Dengan analisis Kajian Budaya menggunakan pendekatan historis diharapkan penelitian ini akan mampu mengungkapkan mengenai suasana masa lampau sebagai citra untuk mengungkapkan kenangan. Hal ini sesuai dengan pendapat Ratna (2010:367) yang menyatakan bahwa daya tarik analisis historis adalah pengungkapannya mengenai suasana masa lampau sebagai citra nostalgia.

\section{Metode}

Penelitian terhadap esai JRPJD karya Pram ini adalah jenis penelitian deskriptif kualitatif yang selanjutnya disebut penelitian kualitatif. Sumber data utama dalam penelitian ini adalah esai JRPJD karya Pram yang diterbitkan Lentera Dipantara - Jakarta cetakan kesembilan pada 2012. Esai sejarah tersebut memunyai ukuran dua puluh x tiga belas cm dengan tebal buku 148 halaman. Sedangkan sumber data pendamping adalah berbagai buku sejarah yang relevan. Data dalam penelitian ini berupa kutipan kata-kata, kalimat, frasa, paragraf, dan wacana yang berasal dari esai JRPJD karya Pram di mana teks tersebut memiliki keterkaitan dengan fokus pembahasan dalam penelitian ini.

Model analisis esai JRPJD ini menggunakan model Kajian Budaya dengan pendekatan historis. Seperti yang telah dibahas dalam bagian pendahuluan bahwa 
ada tiga kemungkinan dalam proses analisis Kajian Budaya dengan pendekatan historis, yaitu: secara implisit, eksplisit, dan dapat juga menganalisis dengan cara menggabungkannya secara eklektik dengan disiplin lain, dengan catatan bahwa secara hierarkis setiap disiplin yang terlibat dapat ditentukan kedudukannya. Namun dalam analisis ini peneliti akan menganalisis dengan cara yang pertama, yaitu secara implisit. Penelitian ini berusaha untuk mengaitkannya dengan ruang lingkup sejarah umum nasional Indonesia.

Cara kerja yang ditempuh peneliti adalah langkah-langkah sebagai berikut. Pertama, membaca secara saksama esai JRPJD karya Pram. Kedua, menandai dan mencatat teks yang memunyai keterkaitan dengan fokus pembahasan yaitu bagaimana representasi peristiwa genosida terhadap orang-orang Indonesia digambarkan dalam esai JRPJD karya Pram. Ketiga, menyajikan dan mengulas data tentang representasi peristiwa genosida terhadap orang-orang Indonesia yang ditulis Pram dalam esai JRPJD. Keempat, peneliti menyajikan klaririfikasi tentang kebenaran Pram merepresentasikan peristiwa genosida terhadap orang-orang Indonesia yang ditulisnya dalam esai JRPJD dengan kenyataan sejarah dari sumber informasi sejarah yang relevan.

\section{PEMBAHASAN}

Seperti telah disebutkan di bagian awal tulisan ini bahwa permasalahan penelitian ini adalah mengaji bagaimana representasi peristiwa genosida terhadap orang-orang Indonesia dalam esai JRPJD karya Pram dan bagaimana klarifikasi sejarah terhadap representasi peristiwa genosida yang telah ditulis Pram dalam esai JRPJD. Pada bagian pembahasan ini peneliti akan memaparkan data yang berkaitan dengan fokus masalah yang dikaji dalam penelitian ini. Pertama, peneliti akan memaparkan data tentang representasi Pram dalam menggambarkan genosida yang pernah terjadi di Indonesia dalam esai JRPJD. Kedua, peneliti akan memberikan klarifikasi/penjelasan terhadap kebenaran peristiwa genosida yang 
Mujihadi, Genosida Terhadap Orang-orang... (hlm. 266-287)

telah ditulis Pram dalam esai JRPJD tersebut dengan kenyataan sejarah yang pernah terjadi di Indonesia. Adapun pembahasan selengkapnya disajikan peneliti sebagai berikut.

\section{Representasi Genosida terhadap Orang-Orang Indonesia dalam Esai JRPJD Karya Pram}

Genosida dapat diartikan sebagai tindakan pembunuhan besar-besaran secara berencana terhadap suatu bangsa atau ras (Tim Penyusun Kamus, Pusat Pembinaan dan Pengembangan Bahasa, 1995:310). Ada dua macam bentuk praktik genosida. Pertama, genosida langsung. Kedua, genosida tidak langsung. Genosida langsung maksudnya adalah pembantaian secara besar-besaran yang dilakukan dengan memakai kekuatan senjata. Sedangkan yang dimaksud dengan genosida tidak langsung adalah peristiwa pembantaian terhadap suatu bangsa/ras lewat aksi tertentu (bukan bersenjata) namun dapat mengakibatkan hilangnya nyawa banyak orang. Menurut hasil penelitian terhadap esai Pram yang berjudul JRPJD, peneliti memeroleh informasi bahwa peristiwa genosida terhadap orangorang Indonesia pernah dilakukan oleh bangsa Belanda, bangsa Jepang, dan oleh bangsa Indonesia sendiri. Peristiwa genosida terhadap orang-orang Indonesia tersebut direpresentasikan Pram dalam esai JRPJD seperti penjelasan di bawah ini.

\section{Genosida terhadap Orang-Orang Indonesia yang Dilakukan oleh Belanda}

Menurut Pram, peristiwa genosida terhadap orang-orang Indonesia yang dilakukan oleh bangsa Belanda sudah terjadi berulang kali. Dalam esai JRPJD, Pram mengungkap bahwa peristiwa pembantaian terhadap orang Indonesia oleh bangsa Belanda itu terjadi pada saat pembuatan jalan raya pos yang terkenal dengan nama Jalan Daendels, pada saat pelaksanaan Sistem Cultuur Stelsel (Tanam Paksa) zaman Johannes van den Bosch, pada saat pembantaian di 
Bandaneira oleh Jan Pieterszoon Coen, dan pembantaian besar-besaran yang dilakukan oleh Kapten Westerling di Maluku.

Kekejaman genosida pertama yang dilakukan oleh bangsa Belanda adalah saat pembangunan proyek jalan raya pos antara Anyer dan Panarukan. Ketika membangun proyek jalan itu, Gubernur Jenderal Daendels melakukan kerja paksa terhadap para pekerja Indonesia. Dalam proyek kerja paksa untuk membangun jalan raya pos inilah banyak pekerja Indonesia tewas. Menurut Pram, genosida inilah yang disebut sebagai genosida tidak langsung. Dikatakan demikian karena ketika pembuatan jalan raya pos ini, memang tidak ada pembantaian secara langsung. Saat itu banyak pekerja proyek yang mati karena dipaksa untuk bekerja keras namun tidak diberi makan secara layak. Representasi tentang berapa jumlah korban yang tewas ketika membangun jalan raya pos itu digambarkan Pram dalam esai JRPJD seperti pada kalimat berikut.

"Untuk berhasilnya proyek pembangunan jalannya, Daendels tidak bergeming melihat ribuan jiwa Pribumi melayang. Sekali lagi laporan orang Inggris pada 1815 itu: seluruh Jalan Raya Pos itu kurban tewas diperkirakan sejumlah 12.000 orang (Toer, 2012:71)."

Dari representasi Pram tersebut kita mengetahui bahwa jumlah kurban tewas akibat kerja paksa ketika membangun jalan raya pos adalah 12.000 orang. Informasi lainnya yang dapat kita peroleh adalah: peristiwa pembangunan jalan raya pos itu terjadi ketika penjajahan Belanda dipimpin Gubernur Jenderal Daendels. Genosida itu dapat dikatakan genosida tidak langsung karena para pekerja itu bukan tewas karena dibantai, tetapi tewas karena terjangkit malaria, kelaparan, dan karena kelelahan. Gambaran tentang tewasnya para pekerja proyek jalan raya pos karena wabah malaria, karena kelaparan, dan kelelahan direpresentasikan oleh Pram dalam esai JRPJD seperti pada kalimat berikut.

"Tak terbilang lagi banyaknya pekerja yang mati, juga karena malaria, juga karena kalaparan, juga karena kelelahan, kata Meneer Guru. "Justru 
di sepanjang Jalan Raya Pos - Jalan Daendels ini - terdapat kuburankuburan terluas di Pulau Jawa. Dan ini bukan pembunuhan besar-besaran pertama yang dilakukan Belanda di tanah air kita! (Toer, 2012:8).”

Peristiwa genosida tidak langsung yang dilakukan Belanda ketika melaksanakan kerja paksa membangun jalan raya pos antara Anyer dan Panarukan, tidak terkonsentrasi hanya pada satu tempat saja. Kurban genosida tidak langsung tersebut tersebar di beberapa daerah di Jawa. Menurut Pram, korban genosida itu tersebar di daerah Banten, Megamendung, Karangsembung/Cirebon, Demak, Kudus, Muria, Sumedang, dan Pekalongan. Karena kurban genosida tidak langsung ini sangat banyak dan tersebar di berbagai wilayah di pulau Jawa, maka Pram menyebut "Justru di sepanjang Jalan Raya Pos - Jalan Daendels ini - terdapat kuburan-kuburan terluas di Pulau Jawa (Toer, 2012:8).” Representasi kurban genosida tidak langsung akibat kerja paksa saat membangun jalan raya pos yang tersebar di beberapa daerah Jawa digambarkan Pram dalam esai JRPJD seperti pada kalimat berikut.

“Tenaga kerja diperintahkan pada Sultan Banten untuk memasok. Dan para pekerjapaksa ini, juga pejabat-pejabat kulit putih, berkaparan mati sebagai tikus, baik karena perlakuan maupun karena penyakit, dan terutama karena kelelahan dan kelaparan (Toer, 2012:20).”

Dari representasi Pram tersebut dapat kita lihat bahwa ketika proyek pembuatan jalan raya pos sampai di Banten, penguasa Belanda memerintahkan kepada Sultan Banten agar menyediakan tenaga kerja paksa. Tenaga kerja paksa tersebut banyak yang tewas karena penyakit, kelelahan, dan kelaparan. Yang lebih tragis lagi adalah kematian mereka digambarkan oleh Pram sebagai kematian yang mengenaskan, berkaparan sebagai tikus yang tidak berharga. Selanjutnya, untuk merepresentasikan adanya genosida tidak langsung di daerah Jawa Barat 
utamanya di daerah Megamendung dan Sumedang, Pram menggambarkan dalam esai JRPJD seperti pada teks berikut ini.

"Dalam membuat jalan yang sulit menembus gunung-gunung tinggi ini dikerahkan 1100 tenaga kerjapaksa. Waktu pembikinan jalan menembus Megamendung 500 tenaga kerjapaksa Pribumi diberitakan tewas. Jumlah tersebut besar kemungkinan telah ditekan (Toer, 2012:21)."

"Penduduk Sumedang bangga pada perlawanan ini. untuk mengenangkannya telah didirikan patung Kornel berhadapan dengan Daendels.//.../. Dalam pembikinan jalan inilah untuk pertama kali ada angka jumlah kurban yang jatuh 5.000 orang. Bahwa angka yang diberikan begitu bulatnya telah menunjukkan tidak rincinya laporan, hanya taksiran (Toer, 2012:70).”

Dari apa yang digambarkan Pram kita dapat mengetahui bahwa kurban tewas ketika membangun jalan raya pos di daerah Megamendung mencapai lima ratus orang. Sedangkan di daerah Sumedang mencapai lima ribu orang. Menurut Pram, jumlah pekerja paksa yang tewas ini pun hanya berupa taksiran kasar. Sementara itu, untuk merepresentasikan tentang kisah genosida di Jawa Tengah utamanya di daerah Pekalongan, Demak, Muria, dan Kudus, Pram menggambarkannya dalam esai JRPJD seperti pada kalimat berikut.

"Dalam membangun jalan menuju ke Pekalongan para pekerjapaksa menerobos hutan belantara yang tidak sehat. Inggris lagi yang memberitakan: kurban tewas 4.000 orang waktu menerobos membikin jalan raya ini (Toer, 2012:84).”

“Sedang waktu menggarap ruas Demak - Kudus memotong semenanjung Muria/Jepara, para pekerja berkaparan dalam meninggikan tanah di rawarawa Karanganyar baik karena kelelahan, perlakuan keras, maupun malaria yang berabad menghantui wilayah Karanganyar (Toer, 2012:26).” 
Kekejaman genosida kedua terhadap orang Indonesia yang dilakukan bangsa Belanda terjadi saat penerapan Sistem Tanam Paksa/Cultuur Stelsel pada zaman Gubernur Jenderal Johannes van den Bosch berkuasa. Peristiwa ini juga dapat digolongkan dalam peristiwa genosida tidak langsung. Genosida tidak langsung ini direpresentasikan oleh Pram dalam esai JRPJD seperti pada kalimat berikut.

"Gubernur Jenderal Van den Bosch memberlakukan Cultuurstelsel alias Tanampaksa. Tak lain dari petani dikerahkan untuk kerjapaksa. Di banyak daerah, demi panen komoditi untuk membiayai penjajahan dan penjajah, ribuan petani Jawa tewas kelaparan karena tak sempat menggarap sawah ladangnya sendiri. Tentu saja keluarganya juga ikut tewas. Di Grobogan sampai-sampai orang tak sempat menguburkan para kurban (Toer, 2012:71)."

"Demak sebagai kabupaten dengan penduduk 336.000 jiwa; karena genosida tak langsung Cultuurstelsel alias Tanampaksa, dua pertiga penduduknya tewas. Menurut catatan Belanda sendiri, dari 336.000 pada 1848/49 itu pada 1850 tinggal 120.000 jiwa...(Toer, 2012:93 - 94 ).”

Genosida tidak langsung yang berlangsung ketika Belanda menerapkan Sistem Tanam Paksa/Cultuur Stelsel menurut Pram telah menewaskan banyak orang di daerah Grobogan dan Demak. Dari representasi Pram tersebut dapat kita ketahui bahwa akibat penerapan Sistem Tanam Paksa di daerah Jawa Tengah banyak rakyat yang tewas. Tercatat oleh Pram bahwa ada sekitar 216.000 orang tewas sehingga digambarkan kurban genosida tidak langsung itu tidak sempat dikubur oleh keluarganya.

Kekejaman genosida yang ketiga dilakukan Belanda adalah pembantaian besar-besar terhadap bangsa Indonesia yang berada di daerah Bandaneira. Menurut Pram, kurban genosida yang dilakukan oleh Gubernur Jenderal Jan 
Pietersz Coen banyak sekali namun tidak pernah tercatat. Gambaran tentang adanya genosida yang pernah terjadi di Bandaneira direpresentasikan Pram dalam esai JRPJD seperti pada kalimat berikut.

"Genosida pertama yang dilakukan Belanda dilakukan oleh Jan Pietersz Coen di bulan-bulan awal pertama 1621 di Bandaneira. Seluruh penduduk binasa. Yang sempat melarikan diri mengungsi ke pulau-pulau lain (Toer, 2012:21 - 22).”

"Berapa orang yang telah jadi kurban genosida Coen? Tidak pernah ada angka disebut. Siapa-siapa kurbannya? Dalam sejarah nama-nama rakyat yang dikurbankan tidak pernah tercatat (Toer, 2012:70).”

Kekejaman genosida keempat yang dilakukan bangsa Belanda terhadap orang Indonesia adalah ketika terjadinya peristiwa pembantaian rakyat Maluku oleh Kapten Westerling. Genosida ini dapat dikatakan sebagai genosida langsung. Dikatakan demikian karena saat itu memang rakyat Maluku dibantai secara kejam dengan menggunakan senjata. Representasi tentang peristiwa itu digambarkan Pram dalam esai JRPJD seperti pada kalimat berikut ini.

"Genosida terakhir yang dilakukan Belanda terjadi pada 1947, di Sulawesi Selatan, oleh pasukan Kapten Westerling. Berapa yang jadi kurban? Manai Sophian menyebut angka 40.000. Memang dari pihak Belanda kemudian ada usaha untuk melakukan penyelidikan yang membuahkan angka 5.000. Tak jelas angka mana yang benar (Toer, 2012:22)."

\section{Genosida terhadap Orang-Orang Indonesia yang Dilakukan oleh Jepang}

Pram mencatat bahwa bangsa Jepang pun pernah melakukan genosida terhadap bangsa Indonesia. Genosida yang dilakukan oleh bangsa Jepang tergolong dalam genosida langsung. Banyak sekali rakyat Indonesia yang tewas mengenaskan dibunuh dengan kekuatan senjata bangsa Jepang. Genosida secara langsung ini pernah terjadi di Kalimantan Barat. Untuk merepresentasikan 
Mujihadi, Genosida Terhadap Orang-orang... (hlm. 266-287)

genosida secara langsung yang pernah dilakukan bangsa Jepang di Kalimantan Barat, Pram menggambarkan dalam esai JRPJD seperti pada kalimat berikut.

"Genosida yang hampir tak pernah diungkit adalah yang dilakukan Jepang di Kalimantan Barat. Sama sekali tak ada angka disebutkan. Juga sama sekali tak pernah ada niat untuk membentuk komisi penyelidikan, sampai sekarang (Toer, 2012:22)

"Genosida langsung malah terjadi pada abad 20. Sekarang yang melakukan balatentara fasis Jepang di Kalimantan Barat. Sampai sekarang tak pernah ada penyelidikan baik dari pihak Jepang maupun Indonesia. Seakan jiwa orang Indonesia memang begitu rendah (Toer, 2012:72).”

Dari gambaran Pram tentang peristiwa genosida secara langsung dalam esai JRPJD, kembali kita dapat mengetahui bahwa seakan nyawa orang Indonesia tidak berharga sama sekali. Buktinya, sampai sekarang kasus ini tidak pernah mendapat perhatian untuk diselidiki. Penyelidikan terhadap kasus ini tidak pernah dilakukan baik oleh pihak Jepang maupun oleh pihak Indonesia sendiri. Berapa jumlah kurban nyawa orang Indonesia pun sampai saat ini tidak diketahui secara pasti.

\section{Genosida terhadap Orang-Orang Indonesia yang Dilakukan oleh Bangsa Indonesia Sendiri}

Pram menyebut bahwa genosida yang dilakukan bangsa Indonesia terhadap bangsanya sendiri sebagai tragedi kemanusiaan yang sangat besar dalam sejarah umat manusia. Ironisnya, peristiwa genosida ini justru dilakukan oleh bangsa Indonesia terhadap bangsa Indonesia itu sendiri. Genosida ini oleh Pram dikatakan sebagai genosida untuk mendirikan Orde Baru. Representasi yang menggambarkan bahwa telah terjadi genosida terhadap bangsa Indonesia yang 
dilakukan oleh bangsa Indonesia sendiri ditulis Pram dalam esai JRPJD seperti tampak pada kalimat berikut ini.

"Genosida terakhir sampai sekarang, salah satu yang terbesar dalam sejarah ummat manusia dalam abad ini, justru dilakukan oleh bangsa Indonesia sendiri. Hanya agar Indonesia bisa menjadi pasar modal dunia (Toer, 2012:23).”

"Kemudian datang genosida Pribumi paroh kedua abad 20. Juga tak jelas berapa jumlah kurban pembantaian. Ada yang menyebut ratusan ribu, sejuta, malah sampai satu setengah juta. Ini adalah genosida untuk mendirikan Orde Baru, yang oleh sementara kalangan Barat dianggap sebagai "berita baik". Memang berita baik bagi modal raksasa internasional untuk membangun neo-kolonialisme di bumi Indonesia (Toer, 2012:72)."

Dari representasi Pram tentang peristiwa genosida di atas, maka kita mengetahui bahwa peristiwa itu terjadi sekitar akhir 1965 - 1966. Peristiwa genosida yang dimaksud adalah genosida untuk menumpas Gerakan 30 September/PKI. Peristiwa itu dipandang Pram selain sebagai peristiwa untuk mendirikan Orde Baru, pihak Barat pun menganggap peristiwa ini sebagai "berita baik" karena bisa menciptakan pasar modal raksasa internasional untuk membangun neo-kolonialisme di bumi Indonesia. Kurban keganasan genosida ini diberitakan mencapai sekitar 1,5 juta orang Indonesia terbunuh.

\section{Klarifikasi Sejarah terhadap Representasi Pram tentang Peristiwa Genosida yang Pernah Terjadi di Indonesia dalam Esai JRPJD.}

Yang dimaksud oleh peneliti dengan istilah klarifikasi adalah usaha peneliti untuk memberi keterangan, penjelasan, dan pencerahan sehingga masalah yang dibahas menjadi lebih jelas. Hal ini sejalan dengan Tim Penyusun Kamus, 
Pusat Pembinaan dan Pengembangan Bahasa yang memberi definisi bahwa klarifikasi maksudnya adalah: penjernihan, penjelasan, dan pengembalian kepada apa yang sebenarnya (1995:507). Dalam memberi klarifikasi terhadap permasalahan yang sedang dibahas, peneliti menempuh jalan dengan cara membandingkan representasi peristiwa genosida yang telah ditulis oleh Pram dalam esai JRPJD dengan berbagai literatur sejarah yang relevan. Dengan jalan seperti ini diharapkan dapat memberi penjelasan terhadap masalah yang sedang dibahas. Perlu juga dipahami bahwa klarifikasi dalam penelitian ini bukan bersifat detail, namun hanya bersifat umum. Hal ini terjadi karena dalam menganalisis Kajian Budaya ini, peneliti menggunakan pendekatan historis yang bersifat implisit. Seperti yang ditulis Ratna (2010:366 - 367) bahwa analisis historis bersifat implisit, fungsinya adalah untuk membantu menjelaskan analisis Kajian Budaya. Daya tarik analisis historis adalah pengungkapannya mengenai suasana masa lampau, sebagai citra nostalgia. Masa lampau dengan sendirinya tidak bisa dikenali secara utuh. Peneliti sengaja tidak menggunakan pendekatan historis secara eksplisit maupun multidisiplin karena peneliti menyadari bahwa peneliti bukan seorang sejarawan.

Seperti dikemukakan pada bagian awal tulisan ini bahwa dalam menganalisis historis secara implisit cara yang paling mudah adalah mengaitkannya dengan sejarah umum, baik dalam ruang lingkup dunia, maupun nasional dan lokal, periode, angkatan, dan zaman (Ratna, 2010:363). Untuk itu dalam mengklarifikasi tentang kebenaran peristiwa genosida yang telah direpresentasikan Pram dalam esai JRPJD, peneliti akan mengaitkannya dengan sejarah umum dalam lingkup nasional. Hasil kajian dari berbagai literatur sejarah dapat dikatakan bahwa apa yang direpresentasikan Pram tentang adanya peristiwa genosida dalam esai JRPJD secara umum memang menunjukkan 
kenyataan/kebenaran sejarah. Hal tersebut dapat kita telusuri pada bukti-bukti sebagai berikut.

Pertama, peristiwa genosida tidak langsung yang dilakukan Daendels. Genosida tidak langsung ini dilakukan Daendels saat mengerjakan proyek jalan pos antara Anyer (Banten) dan Panarukan (Situbondo). Tercatat dalam sejarah bahwa Daendels (1762 - 1818) ketika menjadi gubernur jenderal di Hindia Belanda memunyai dua tugas besar. Kedua tugas besar itu adalah: pertama, mempertahankan Pulau Jawa agar jangan sampai jatuh ke tangan Inggris; kedua, memperbaiki keadaan tanah jajahan dari berbagai aspek (terutama penyelewengan dan korupsi). Adapun langkah-langkah yang ditempuh Daendels untuk menyukseskan program tersebut salah satu di antaranya adalah membangun jalan raya antara Anyer - Panarukan dengan tujuan agar tentaranya dapat bergerak secara cepat. Proyek jalan ini juga dimaksudkan agar mempermudah pengangkutan kopi dari daerah pedalaman. Untuk mempercepat terwujudnya jalan raya pos ini Daendels memerintahkan rakyat untuk melakukan program kerja paksa (Hapsari dan Adil, 2012:53). Dalam proyek kerja paksa inilah banyak rakyat Indonesia tewas karena kelaparan, kelelahan, maupun karena wabah penyakit.

Kedua, peristiwa genosida tidak langsung ketika Belanda melaksanakan Sistem Tanam Paksa/Cultuur Stelsel yang dicetuskan oleh Johannes van den Bosch. Sejarah mencatat bahwa peristiwa ini memang benar-benar pernah terjadi di Indonesia. Cultuur Stelsel secara harfiah dapat dikatakan sebagai "sistem budaya". Tetapi orang-orang Indonesia sering menyebut Cultuur Stelsel sebagai Tanam Paksa karena rakyat dipaksa untuk menanam tanaman ekspor yang hasilnya harus dijual kepada Belanda. Tanaman primadona yang ditanam ketika dilaksanakan Sistem Tanam Paksa ini adalah kopi. Dipilih kopi karena harganya yang sangat tinggi di pasar dunia (Hapsari dan Adil, 2012:59). Selanjutnya juga dikatakan oleh Hapsari dan Adil bahwa Tanam Paksa ini dilaksanakan bertahap 
mulai tahun 1830 - 1835. Di Jawa tercatat ada delapan belas karesidenan yang digunakan untuk penerapan Sistem Tanam Paksa. Daerah yang dimaksud adalah: Banten, Priangan, Kerawang, Cirebon, Tegal, Pekalongan, Banyumas, Kedu, Bagelen, Semarang, Jepara, Rembang, Surabaya, Pasuruan, Besuki, Pacitan, Madiun, dan Kediri (2012:59).

Ketiga, peristiwa genosida yang dilakukan oleh Jan Pietersz Coen. Peristiwa pembantaian terhadap rakyat Indonesia yang dilakukan oleh Belanda/VOC di Bandaneira ini terjadi saat VOC dipimpin Jan Pietersz Coen. Sejarah mencatat bahwa salah satu program J.P. Coen untuk memonopoli cengkeh dan pala di Maluku (termasuk Banda) adalah dengan cara mengusir dan melenyapkan penduduk asli Banda. Ketika mewujudkan keinginannya tersebut banyak rakyat Banda yang dieksekusi. Penduduk yang berhasil melarikan diri lari ke pegunungan dan menderita kelaparan. Orang-orang Banda yang tertangkap tetapi masih hidup lalu diangkut dengan kapal menuju Batavia. Ada 883 orang, terdiri atas: 287 pria, 356 wanita, dan 240 anak-anak dibawa ke Batavia. Dalam perjalanan tersebut tercatat sebanyak 176 orang binasa karena kelaparan dan perlakuan yang tidak manusiawi. (Hapsari dan Adil, 2012:43).

Keempat, peristiwa pembantaian oleh Kapten Westerling. Sejarah mencatat bahwa peristiwa ini memang benar-benar pernah terjadi di Indonesia. Kartasasmita, dkk. mencatat bahwa pada Desember 1946 Belanda mengirimkan pasukan di bawah pimpinan Kapten Westerling ke Sulawesi Selatan. Sejak kedatangannya tanggal 7 - 25 Desember 1946, pasukan Westerling secara membabi buta telah membunuh beribu-ribu rakyat. Operasi ini dimaksudkan sebagai tindakan "membersihkan" daerah Sulawesi Selatan dari pejuang Republik Indonesia. Gerakan "pembersihan” ini dilakukan oleh Kapten Westerling pada bulan Desember 1946 pascapertempuran dengan pasukan "Harimau Indonesia" 
yang dipimpin Mongisidi di Barombong tanggal 3 November 1946 (1981:126 127).

Kelima, genosida Jepang di Kalimantan Barat. Sejarah mencatat telah terjadi genosida langsung di Kalimantan Barat yang dilakukan oleh Jepang. Kurban genosida di Kalimantan Barat ini mencapai puluhan ribu orang. Jepang mencurigai bahwa di Kalimantan Barat ada kelompok yang terdiri atas feodal lokal, cerdik-pandai, ambtenar, politisi, tokoh masyarakat, tokoh agama, hingga rakyat jelata, dari berbagai etnik, suku maupun agama. Kelompok tersebut kemudian dihancurkan dengan penangkapan yang terjadi antara September 1943 dan awal 1944. Usman Syafaruddin dan Isnawita Din (2009:70) mencatat bahwa kurban keganasan genosida ini mencapai lebih kurang 21.037 orang. Para kurban diduga dipancung hidup-hidup dengan samurai setelah kepalanya ditutupi dengan sungkup. Karena pembantaian itu terjadi di daerah Mandor, maka sering disebut Peristiwa Mandor Berdarah. Untuk memperingati kekejaman pembantaian tersebut, maka lahir Peraturan Daerah (Perda) Provinsi Kalimantan Barat Nomor 5 Tahun 2007 yang memutuskan bahwa Peristiwa Mandor (28 Juni) dijadikan sebagai Hari Berkabung Daerah (HBD). Hal ini dilakukan sebagai bentuk kepedulian sekaligus apresiasi dari DPRD Kalimantan Barat terhadap perjuangan pergerakan nasional yang terjadi di Mandor. Masyarakat Kalimantan Barat untuk kali pertama pada tanggal 28 Juni 1997 diimbau untuk mengibarkan bendera setengah tiang sebagai tanda berkabung atas malapetaka yang ditimbulkan akibat penjajahan Jepang mulai 1942 - 1945 (Usman dan Isnawita Din, 2009:69).

Keenam, genosida langsung yang dilakukan oleh orang Indonesia terhadap orang Indonesia sendiri. Genosida ini terjadi di Indonesia pada pengujung tahun 1965 - akhir 1966 yang merupakan operasi penghancuran G-30-S/PKI oleh militer. Mengenai berapa jumlah kurban memang sangat simpang-siur. Hal ini dikarenakan koran-koran saat itu mengalami pemberangusan. Roosa menyatakan bahwa saat itu memang koran-koran Indonesia tidak memberitakan adanya 
pembunuhan. Angkatan Darat memberangus hampir semua surat kabar dalam pekan pertama Oktober 1965 dan menerapkan sensor terhadap beberapa surat kabar yang diizinkan terbit kembali. Angkatan Darat menerbitkan beberapa korannya sendiri. Orang akan sia-sia mencari berita dalam koran-koran yang terbit antara akhir 1965 sampai akhir 1966 yang sekadar menyebut saja bahwa ada pembunuhan besar-besaran (2008:29). Sebagai gambaran kasar, Karnow dari Washington Post menyatakan bahwa setelah melalui perjalanan selama dua pekan di seluruh Jawa dan Bali, Karnow memperkirakan setengah juta orang mati dibunuh dalam peristiwa ini (dalam Roosa, 2008:30).

\section{SIMPULAN}

Dari pembahasan tentang bagaimana bentuk representasi peristiwa genosida terhadap orang-orang Indonesia pada esai JRPJD karya Pram dan bagaimana klarifikasi sejarah terhadap representasi Pram tentang peristiwa genosida tersebut, peneliti memberi simpulan sebagai berikut. Dalam esai tersebut penulis (Pram) mengisahkan bahwa telah terjadi genosida terhadap orang-orang Indonesia. Genosida yang pernah terjadi di Indonesia itu dapat dikelompokkan menjadi tiga macam. Ketiga macam bentuk genosida itu adalah: pertama, genosida yang dilakukan bangsa Belanda (berupa genosida yang terjadi ketika membuat proyek jalan raya pos oleh Daendels, genosida Jan Pietersz Coen di Bandaneira, genosida Westerling di Sulawesi Selatan, dan genosida zaman penerapan Cultuur Stelsel/Tanam Paksa oleh Johannes van den Bosch); kedua, genosida yang terjadi saat penjajahan Jepang (berupa pembunuhan yang terjadi di Kalimantan Barat); dan ketiga, genosida yang dilakukan oleh bangsa Indonesia sendiri (berupa genosida terhadap orang-orang Indonesia oleh bangsa Indonesia sendiri berkaitan erat dengan penumpasan Gerakan 30 September/PKI yang terjadi sekitar akhir 1965 - 1966). Peritiwa genosida terhadap orang-orang 
Indonesia yang telah direpresentasikan oleh Pram dalam esai JRPJD itu jika diklarifikasi dengan sejarah Indonesia, maka secara umum dapat dikatakan bahwa peristiwa tersebut adalah merupakan peristiwa sejarah yang memang benar-benar pernah terjadi di Indonesia.

\section{Saran}

Penelitian Kajian Budaya dengan menggunakan pendekatan historis terhadap esai JRPJD karya Pram ini hanya menganalisis secara implisit saja. Oleh karena itu peneliti selalu berharap kepada peneliti berikutnya agar berkenan untuk melakukan penelitian dengan menggunakan pendekatan historis lainnya. Baik menggunakan analisis historis secara eksplisit maupun multidisplin. Analisis historis baik secara eksplisit maupun multidiplin akan mampu menghasilkan analisis yang mendalam dan beragam. Dengan hasil analisis historis yang mendalam dan beragam, maka analisis Kajian Budaya dengan pendekatan historis terhadap esai JRPJD karya Pram tersebut akan semakin lengkap.

\section{DAFTAR PUSTAKA}

Faruk. 2012. Metode Penelitian Sastra: Sebuah Penjelajahan Awal. Yogyakarta: Pustaka Pelajar.

Hapsari, Ratna dan M. Adil. 2012. Sejarah Indonesia untuk SMA/Ma Kelas XI 2. Jakarta: Penerbit Erlangga.

Kartasasmita, Ginanjar, dkk. 1981. 30 Tahun Indonesia Merdeka: 1945 - 1949. Jakarta: PT Tira Pustaka.

Ratna, Nyoman Kutha. 2010. Metodologi Penelitian Kajian Budaya dan Ilmu Sosial Humaniora pada Umumnya. Yogyakarta: Pustaka Pelajar. . 2013. Teori, Metode, dan Teknik Penelitian Sastra. Yogyakarta: Pustaka Pelajar.

Roosa, John. 2008. Dalih Pembunuhan Massal: Gerakan 30 September dan Kudeta Suharto. Terjemahan Hersi Setiawan dari Pretext for Mass Murder: 
Mujihadi, Genosida Terhadap Orang-orang... (hlm. 266-287)

The September 30 ${ }^{\text {th }}$ Movement and Suharto's Coup d'Etat in Indonesia (2006). Jakarta: Hasta Mitra.

Tim Penyusun Kamus, Pusat Pembinaan dan Pengembangan Bahasa. 1995.

Kamus Besar Bahasa Indonesia: Edisi Kedua. Jakarta: Penerbit Balai Pustaka.

Toer, Pramoedya Ananta. 2012. Jalan Raya Pos, Jalan Daendels. Jakarta: Lentera Dipantara.

Usman, Syafaruddin dan Isnawita Din. 2009. Peristiwa Mandor Berdarah:

Eksekusi Massal 28 Juni 1944 oleh Jepang. Jakarta: MedPress 